Estela Arcos'

Ximena Sanchez"

Maria Cecilia Toffoletto'

Margarita Baeza"II

Patricia Gazmuri'

Luz Angélica Muñoz'

Antonia Vollrath'

Facultad de Enfermería. Universidad Andrés Bello. Santiago, Chile

" Facultad de Ciencias Sociales. Universidad de Playa Ancha. Valparaíso, Chile

III Programa de Postgrado en Enfermería, Facultad de Enfermería, Universidad Andrés Bello. Santiago, Chile

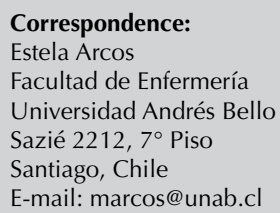

\section{Social protection systems in vulnerable families: their importance for the public health}

\section{Sistemas de protección social en familias vulnerables: su importancia en la salud pública}

\begin{abstract}
OBJECTIVE: To analyze the effectiveness of the Chilean System of Childhood Welfare in transferring benefits to socially vulnerable families.

METHODS: A cross-sectional study with a sample of 132 families from the Metropolitan Region, Chile, stratified according to degree of social vulnerability, between September 2011 and January 2012. Semi-structured interviews were conducted with mothers of the studied families in public health facilities or their households. The variables studied were family structure, psychosocial risk in the family context and integrated benefits from the welfare system in families that fulfill the necessary requirements for transfer of benefits. Descriptive statistics to measure location and dispersion were calculated. A binary logistic regression, which accounts for the sample size of the study, was carried out.
\end{abstract}

RESULTS: The groups were homogenous regarding family size, the presence of biological father in the household, the number of relatives living in the same dwelling, income generation capacity and the rate of dependency and psychosocial risk ( $p \geq 0.05$ ). The transfer of benefits was low in all three groups of the sample $(\leq 23.0 \%)$. The benefit with the best coverage in the system was the Single Family Subsidy, whose transfer was associated with the size of the family, the presence of relatives in the dwelling, the absence of the father in the household, a high rate of dependency and a high income generation capacity $(\mathrm{p} \leq 0.10)$.

CONCLUSIONS: The effectiveness of benefit transfer was poor, especially in families that were extremely socially vulnerable. Further explanatory studies of benefit transfers to the vulnerable population, of differing intensity and duration, are required in order to reduce health disparities and inequalities.

DESCRIPTORS: Health Vulnerability. Health Inequalities. Social Inequity. Social Assistance. Health Economics. Cross-Sectional Studies. Chile. 


\section{RESUMEN}

OBJETIVO: Analizar la efectividad de las transferencias de beneficios del Sistema de Protección Integral de la Infancia a familias de Chile socialmente vulnerables.

MÉTODOS: Estudio transversal analítico con 132 familias, estratificadas según vulnerabilidad social en la Región Metropolitana, Chile, entre septiembre de 2011 y enero de 2012. Se aplicó entrevista semiestructurada a madres de familias en centros de salud públicos o en sus domicilios. Las variables fueron: estructura familiar, riesgo psicosocial del entorno familiar y beneficios integrados del sistema de protección social requeridos en las familias que cumplían con el requisito de aplicabilidad para la transferencia del beneficio. Se calcularon estadígrafos descriptivos, de posición y dispersión. Fue realizada regresión logística binaria, pertinente por el tamaño de la muestra.

RESULTADOS: Los grupos fueron homogéneos en cuanto a tamaño de la familia, presencia del progenitor y número de allegados, capacidad generadora de ingresos, tasa de dependencia y riesgo psicosocial $(p \geq 0,05)$. La transferencia de los beneficios fue baja en los tres grupos $(\leq 23,0 \%)$. La mejor cobertura estuvo representada por el Subsidio Único Familiar, cuya entrega se relacionó con el tamaño de la familia, la presencia de allegados, progenitor ausente, la alta tasa de dependencia y alta capacidad generadora de ingresos $(p \leq 0,10)$.

CONCLUSIONES: La efectividad de entrega de los beneficios fue baja, especialmente en familias de extrema vulnerabilidad social. Nuevos estudios explicativos de formas de transferencia de beneficios deben ser realizados con diferentes niveles de intensidad y tiempos de exposición en poblaciones vulnerables, para disminuir las disparidades y desigualdades en salud.

DESCRIPTORES: Vulnerabilidad en Salud. Desigualdades en la Salud. Inequidad Social. Asistencia Social. Economía de la Salud. Estudios Transversales. Chile.

\section{INTRODUCTION}

Chile has the highest human development index and the lowest poverty rate in Latin America and has one of the highest levels of per capita income in the region. ${ }^{22} \mathrm{At}$ the same time, it has one of the highest inequality rates in Latin America and is the Organization for Economic Cooperation and Development $\left(\mathrm{OECD}^{\mathrm{a}}\right)^{5,22}$ country with the most inequality, leading to profound inequalities and differences that are unfair, avoidable and unnecessary. ${ }^{9,21}$ Poor families bear the main burden of persisting disadvantage, manifested in: social behavior problems, functional instability and precariousness of assets, negatively affected emotional ties and solidarity and health inequalities. ${ }^{12,14,22,24}$

Adverse social conditions in the families are underlying determinants that contribute to deteriorating health, leading to more illness and greater demand for health care. Disparities in health are an objective expression of the socioeconomic disadvantages accumulated by the individuals throughout their lifetime and that should be avoided with timely intervention strategies, the intensity and duration of which would vary according to the degree of vulnerability. ${ }^{3,4,18,19}$

Public social protection policy provides the opportunity to make up for these lacks, at both the individual and family level, ensuring universal access to services, benefits and transfers from public institutions. ${ }^{\mathrm{b}}$ Similar focus has been described in studies in countries with a welfare state. ${ }^{9,15,18,19}$

A recommended way to reduce avoidable health inequalities is by implementing compensatory social policy focusing on early childhood and adolescence, $3,12,16,18$

a Organization for Economic Co-operation and Development. OECD. Economic surveys Chile. Santiago de Chile; 2012 [cited 2013 Jan]. Available from: http://www.oecd.org/eco/49398281.pdf

b Ministerio de Planificación y Cooperación de Chile. Más y mejor protección social para Chile: memoria 2006-2010. Santiago de Chile: Protege; 2010. 
as these are the stages that: (i) provide the best opportunity to level out inequalities and maximize healthy living trajectories ${ }^{9,15,18}$ and (ii) are the most effective in reducing inequality, especially when integrated with a national development strategy. ${ }^{7,16,18}$

The importance of the impact of socioeconomic determinants on Chilean children's health has been recognized. This can be seen in the implementation of the Chilean System of Childhood Welfare public policy, Chile Crece Contigo (ChCC - Chile is Growing with

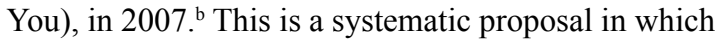
diverse public services converge to ensure that opportunities for children and their families, especially the $40.0 \%$ poorest, are maximized, from pregnancy to four years of age. ${ }^{1}$ Pregnancy is the gateway to the $\mathrm{ChCC}$ and enables mother, child and family to be linked to other support programs, if they meet the conditions. The aim is to reduce health inequalities affecting the first four years of a child's life, ensuring access to services, both universal and differentiated towards them, their mothers and their families. The model used in executing this social policy is one of integrated management between social sectors and disciplines. Collaboration, cooperation, communication and longitudinal continuity of care are essential in promoting, constructing and/or reinforcing individual and collective behavior that enables them to overcome their condition of vulnerability. ${ }^{3, b}$

Regular evaluation of the policies and interventions is essential in order to establish whether observed changes in health, both positive and negative, can be attributed to the intervention. ${ }^{9,18}$ There is consensus on the limitations of evaluating the impact of health inequality indicators. However, the urgent need to produce empirical evidence on what does and does not function in practice is also recognized. ${ }^{9}$ A study on the effectiveness of the ChCC in 132 vulnerable mothers and children highlighted that universal benefit transfer did not attain expected coverage $(100 \%)$, with better results observed in children than in their mothers. It was found that the observed effectiveness of access in dyads at psychosocial risk varied between $57.1 \%$ and $73.8 \%$, in the case of universal benefits, and between $18.0 \%$ and $22.0 \%$ in benefits aimed at the children. In mothers at psychosocial risk, access to universal benefits did not exceed $60.0 \%$, and $40.0 \%$ in differentiated benefits. ${ }^{2}$

The aim of this study was to analyze the effectiveness of the Chilean System of Childhood Welfare benefit transfer to socially vulnerable families.

\section{METHODS}

This was an analytical cross-sectional study of 1,514 families cared for in public health care facilities in the
Metropolitan Region, Chile. The mothers (index cases) entered the ChCC system in 2009 and were classed as social vulnerable by the Chilean Ministry of Planning (MIDEPLAN) based on their score ( $\leq 11,734$ points) on the Social Protection Card.

The families were grouped into three strata: extremely vulnerable ( $\leq 4,213$ points); moderately vulnerable $(4,214$ to 8,500 points) and slightly vulnerable $(8,501$ to 11,734 points). A stratified sample design with proportional allocation was used to accurately represent the population's characteristics and ensure participation of the elements of each strata, which are internally homogenous and externally heterogeneous. The sample size was estimated assuming maximum variance and with a $95 \%$ confidence interval. Estimated error for the population was $0.076(7.6 \%)$ and for strata 1,2 and 3 it was $0.105(10.5 \%), 0.133(13.3 \%)$ and $0.186(18.6 \%)$, respectively. Some units of analysis were replaced from the health center records, due to non updated or inaccurate addresses, safeguarding the strata sampling procedures. The family was the unit of analysis and the mother registered with the $\mathrm{ChCC}$ (index case) was interviewed. The instrument was used with 132 families; 77 extremely vulnerable (stratum 1), 44 moderately vulnerable (stratum 2) and 18 slightly vulnerable (stratum 3 ).

A semi-structured interview was conducted with the mother. The open questions were read, analyzed, categorized and codified for incorporation in the study database. The procedure consisted of finding and naming the general patterns of similar or common responses, listing these patterns and assigning a numerical value or symbol to them. Each pattern constituted a response category. The instrument was applied by researchers either in the health care facilities or in the interviewee's home, between September 2011 and January 2012. In women whose memories of their past was vague, data were completed from the $\mathrm{ChCC}$ system records and the Social Protection Card. We were not authorized to review medical records.

The variables analyzed were: family structure, presence of the biological father in the home; family size and type; elder adult presence within the home; presence of disabled individuals; rate of dependency and capacity to generate income (low, 216 dollars or less/high, over 216 dollars); psychosocial risk in the family context (living conditions; sanitation and hygiene in the home; mental health problems; intra-family violence; drug abuse; childcare conditions; safety of the surrounding environment and child abuse) and welfare system integrated benefits (single family subsidy; drinking water subsidy; basic pension; welfare pension; Sistema Chile Solidario family protection grant; Puente program

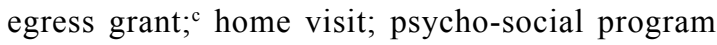

c Ministerio de Desarrollo Social de Chile, Sistema de Protección Social. Qué es Chile Solidario? Santiago de Chile; 2004 [cited 2014 Mar 19]. Available from: http://www.chilesolidario.gob.cl/sist/sist1.php 
support; rehabilitation for addiction; child abuse support; improved living conditions; technical support with housing; legal support; egress grant; psychosocial support program; remedial education courses; vocational training; disability support and integrating older adults into the Programa Vínculos - connections program).,

The families' rate of dependency is calculated as the relationship between the number of economically dependent individuals per 100 active individuals. ${ }^{d}$ Values $<2$ are classed as low dependence, and those $\geq 2$ as high dependence. The family's capacity to generate income (IGC) was calculated based on average $1^{\text {st }}, 2^{\text {nd }}$ and $3^{\text {rd }}$ income quintiles for the segments in question, according to data from the Caracterización Socioeconómica Nacional (National Socioeconomic Classification CASEN 2011) survey for the population residing in the community where the study was carried out. ${ }^{\mathrm{e}}$ Mean income was calculated for individuals: $<15$ years old, students $\geq 15$ years old, pregnant women, mothers with children $<2$ years old, women $>60$ years old and men $\geq 65$ years old and non-independent disabled individuals in the community. In the case of those $<15$ years old, students $\geq 15$ years old, pregnant women, mothers with children $<2$ years old, IGC was estimated for each group separately by estimating mean independent income. For adults $>60$ and 65 years old and for non-independent disabled individuals, mean income was calculated based on retirement and disability pensions, respectively. Mean income obtained for each of these groups was multiplied by the quantity of individuals in each respective group. Independent income was included in the equation, leaving out individuals with any condition affecting their income from the total size of the household. The resulting values were summed and divided by the size of the household, considering its members, to obtain per capita household income. IGC distribution was normal and was dichotomized based on mean value. Values below US\$216 (\$110,028 Chilean pesos) were classed as poor income generating capacity; those above US\$216, as high income generating capacity.

It was decided to use binary logistic regression to produce profiles of families receiving benefits, which resulted in reduced sample size, given the characteristics of the variables studied. The chance of success in obtaining a specific benefit was estimated according to different variables of interest using data modelling. A subsample that had actually applied for the benefit (family subsidy) was selected to generate a population profile. The dependent variable was the interview question: Were you granted the Family Subsidy?, the response categories being "yes" or "no".
The independent variables were categorical variables and included the following questions: "Do relatives share your home?" and "Is the father living in the home?". Three variables, originally scale variables, were dichotomized according to their characteristics: family size, rate of dependency and household income producing capacity. The median was used as a cutoff point for family size and the rate of dependency, as distribution was not normal. Families were classified as small and medium (between one and five members) and large (more than five).

Dispersion and location descriptive statistics were calculated according to the type of variable. The Chi-square test, with a $95 \%$ confidence interval, was used to determine association between structural characteristics and psycho-social risk in the families, according to strata of vulnerability, with the corresponding statistical corrections, specifically, Cramer's $\mathrm{V}$, set out in asymmetrical tables ( $\mathrm{k} \times \mathrm{n})$. The relationship between the families' characteristics and the corresponding benefits was analyzed using binary logistic regression. The benefit with the best representation was selected to generate the profile of the family type with greater access possibilities, with a $90 \%$ confidence interval.

Statistical analysis of the data was conducted using the Statistical Package Social Sciences (SPSS) version 18.0 program.

The study was approved by the Research Ethics Committee of the Faculty of Nursing, Universidad Andrés Bello (protocol L1/CECENF/14) and authorized by the community's Municipal Social Development Corporation. The mothers signed an informed consent form.

\section{RESULTS}

The families were homogenous ( $p \geq 0.05)$ in terms of size (between four and nine individuals per family). Around 50.0\% were nuclear and 50.0\% extended families. In $1 / 3$ and half of them, respectively, the father was absent and there were few older adults present. There were disabled individuals or caregivers present in fewer than $7.0 \%$. The IGC variable was distributed homogenously between the families, as around $50.0 \%$ were on incomes below US\$216, and the rest on incomes above this amount (Table 1).

In the extremely vulnerable stratum, one in every two families had adverse psycho-social determinants (Table 2), related to the high frequency of mental health problems, intra-family violence and drug use $(\mathrm{p} \geq 0.05)$. Greater probability of unsafe surroundings for the child was

${ }^{\mathrm{d}}$ Dependence Rate: DR $=\frac{\text { (Population }<16 \text { years old }+ \text { Población }>65 \text { years old })}{(\text { Popultion betwe } 16 \text { and } 65)}$ (Population between 16 and 65)

e Ministerio de Desarrollo Social de Chile. Encuesta CASEN: base de datos secundarias de la Encuesta de Caracterización Socioeconómica. Santiago de Chile; 2011 [cited 2014 Mar 19]. Available from: http://observatorio.ministeriodesarrollosocial.gob.cl/casen_usuarios.php 
Table 1. Distribution of families' structural characteristics according to strata of vulnerability. Metropolitan Region, Chile, 2012. $(N=132)$

\begin{tabular}{|c|c|c|c|c|c|c|c|}
\hline \multirow{3}{*}{ Sociodemographic characteristics } & & \multicolumn{6}{|c|}{ Social vulnerability ${ }^{a}$} \\
\hline & & \multicolumn{2}{|c|}{ Extreme } & \multicolumn{2}{|c|}{ Moderate } & \multicolumn{2}{|c|}{ Slight } \\
\hline & & $\mathrm{n}$ & $\%$ & $\mathrm{n}$ & $\%$ & $\mathrm{n}$ & $\%$ \\
\hline \multirow[t]{2}{*}{ Father living in the home } & Yes & 36 & 51.4 & 25 & 56.8 & 12 & 66.7 \\
\hline & No & 34 & 48.6 & 19 & 43.2 & 6 & 33.3 \\
\hline \multirow[t]{2}{*}{ Size (individuals) } & 1 to 3 & 8 & 11.4 & 10 & 22.7 & 2 & 11.1 \\
\hline & $\geq 4$ & 62 & 88.6 & 34 & 77.3 & 16 & 88.9 \\
\hline \multirow[t]{2}{*}{ Family type } & Nuclear & 33 & 47.1 & 25 & 56.8 & 9 & 50.0 \\
\hline & Extended & 37 & 52.9 & 19 & 43.2 & 9 & 50.0 \\
\hline \multirow[t]{2}{*}{ Relatives sharing the home } & Yes & 38 & 54.2 & 25 & 56.8 & 9 & 50.0 \\
\hline & No & 32 & 45.8 & 17 & 43.2 & 9 & 50.0 \\
\hline \multirow[t]{2}{*}{ Older adults in the home } & Yes & 19 & 27.1 & 9 & 20.5 & 6 & 33.3 \\
\hline & No & 51 & 72.9 & 35 & 79.5 & 12 & 66.7 \\
\hline \multirow[t]{2}{*}{ Rate of dependency } & High $(\geq 2)$ & 33 & 48.5 & 21 & 51.2 & 9 & 50.0 \\
\hline & $\operatorname{Low}(<2)$ & 35 & 51.5 & 20 & 48.8 & 9 & 50.0 \\
\hline \multirow[t]{2}{*}{ Income generating capacity } & Low & 27 & 45.8 & 20 & 50.0 & 8 & 50.0 \\
\hline & High & 32 & 54.2 & 20 & 50.0 & 8 & 50.0 \\
\hline
\end{tabular}

${ }^{a} p \geq 0.05$

b Variables dichotomized based on their mean.

also observed, both in terms of care quality and in living conditions. No association was found between the strata of vulnerability and the risks detected ( $\mathrm{p} \geq 0.05$, Table 2$)$.

Being socially vulnerable, recognized officially using the Social Protection Card, provides the families with opportunities to access community support networks. Access was poor in the three groups (the extremely vulnerable; moderately vulnerable and slightly vulnerable), both for the Puente program (14.3\%; 9.1\% and $5.5 \%$, respectively) and the Chile Solidario program $(14.3 \% ; 9.1 \%$ and $5.5 \%$, respectively). Only one instance of using the Vinculos program was recorded.
In those families that met the requirements for receiving integrated benefits, a wide gap was observed between strata in terms of effectiveness of this benefit, with it being especially low in the most socially vulnerable families $(12.5 \%$; $16.5 \%$ and $22.6 \%$, respectively, that is: extremely, moderately and slightly vulnerable). The most effective integrated benefits were the Single Family Subsidy, followed by the Drinking Water Subsidy and the Basic Pension (Table 3).

Binary regression results show that the chance of receiving the benefit was three times higher in homes shared with relatives, compared with those with no

Table 2. Presence of psycho-social risk in the family context and distribution of recognized causes according to social vulnerability. Metropolitan Region, Chile, 2012. ( $=132)$

\begin{tabular}{|c|c|c|c|c|c|c|}
\hline \multirow{3}{*}{ Psycho-social risk } & \multicolumn{6}{|c|}{ Social vulnerability ${ }^{a}$} \\
\hline & \multicolumn{2}{|c|}{ Extreme } & \multicolumn{2}{|c|}{ Moderate } & \multicolumn{2}{|c|}{ Slight } \\
\hline & $\mathrm{n}$ & $\%$ & $\mathrm{n}$ & $\%$ & $\mathrm{n}$ & $\%$ \\
\hline At psycho-social risk & 33 & 46.5 & 12 & 27.3 & 7 & 38.9 \\
\hline \multicolumn{7}{|l|}{ Recognized causes } \\
\hline Mental health problems & 22 & 66.7 & 9 & 75.0 & 3 & 42.9 \\
\hline History of family violence & 10 & 30.3 & 3 & 25.0 & 2 & 28.6 \\
\hline Substance abuse & 9 & 27.3 & 3 & 25.0 & 0 & 0.0 \\
\hline Deficient childcare & 8 & 24.4 & 4 & 33.3 & 0 & 0.0 \\
\hline Housing problems & 7 & 21.2 & 3 & 25.0 & 0 & 0.0 \\
\hline Sanitation and hygiene problems & 7 & 21.2 & 2 & 16.7 & 2 & 28.6 \\
\hline Unsafe environment & 5 & 15.2 & 2 & 16.7 & 0 & 0.0 \\
\hline Child abuse & 1 & 3.0 & 0 & 0.0 & 0 & 0.0 \\
\hline
\end{tabular}


Table 3. Effectiveness of benefit transfer (EBT) when family meets conditions (Applies), according to strata of social vulnerability. Metropolitan Region, Chile, 2012.

\begin{tabular}{|c|c|c|c|c|c|c|c|c|c|}
\hline \multirow{4}{*}{ Integrated benefit } & \multicolumn{9}{|c|}{ Social vulnerability } \\
\hline & \multicolumn{3}{|c|}{ Extreme } & \multicolumn{3}{|c|}{ Moderate } & \multicolumn{3}{|c|}{ Slight } \\
\hline & \multirow{2}{*}{$\begin{array}{c}\text { Apply } \\
\text { Total }\end{array}$} & \multicolumn{2}{|c|}{ EBT } & \multirow{2}{*}{$\frac{\text { Apply }}{\text { Total }}$} & \multicolumn{2}{|c|}{ EBT } & \multirow{2}{*}{$\frac{\text { Apply }}{\text { Total }}$} & \multicolumn{2}{|c|}{ EBT } \\
\hline & & $\mathrm{n}$ & $\%$ & & $\mathrm{n}$ & $\%$ & & $\mathrm{n}$ & $\%$ \\
\hline Single Family Subsidy & 53 & 29 & 54.7 & 25 & 9 & 36.0 & 10 & 4 & 40.0 \\
\hline Drinking Water & 58 & 11 & 18.9 & 4 & 3 & 75.0 & 1 & 1 & 100 \\
\hline Basic Pension & 12 & 4 & 33.3 & 4 & 1 & 25.0 & 1 & 1 & 100 \\
\hline Welfare Pension & 12 & 3 & 25.0 & 5 & 0 & 0.0 & 1 & 1 & 100 \\
\hline Family Protection Grant & 65 & 6 & 9.2 & 2 & 0 & 0.0 & 1 & 0 & 0.0 \\
\hline Domestic Visit & 45 & 4 & 4.4 & 18 & 1 & 5.5 & 6 & 0 & 0.0 \\
\hline Rehabilitation for addiction & 14 & 1 & 7.1 & 6 & 1 & 16.6 & 2 & 0 & 0.0 \\
\hline Child abuse support & 11 & 1 & 9.1 & 5 & 0 & 0.0 & 0 & 0 & 0.0 \\
\hline Improved living conditions & 62 & 1 & 1.6 & 3 & 0 & 0.0 & 0 & 0 & 0.0 \\
\hline Technical housing support & 60 & 1 & 1.6 & 2 & 0 & 0.0 & 0 & 0 & 0.0 \\
\hline Legal support & 2 & 1 & 50.0 & 0 & 0 & 0.0 & 0 & 0 & 0.0 \\
\hline Egress grant & 64 & 1 & 1.6 & 3 & 0 & 0.0 & 0 & 0 & 0.0 \\
\hline Psycho-social support program & 41 & 1 & 2.4 & 17 & 1 & 5.8 & 5 & 0 & 0.0 \\
\hline Remedial education & 5 & 0 & 0.0 & 4 & 0 & 0.0 & 1 & 0 & 0.0 \\
\hline Vocational training & 7 & 0 & 0.0 & 2 & 0 & 0.0 & 1 & 0 & 0.0 \\
\hline Disability support & 3 & 0 & 0.0 & 3 & 1 & 33.3 & 2 & 0 & 0.0 \\
\hline
\end{tabular}

relatives. The chance of receiving the benefit was $86.5 \%$ lower when the father was living in the home, compared with households in which the father was absent, as social vulnerability and dependence is greater when the father is absent. The chances of receiving the benefit were $75.6 \%$ lower in large families, compared to small families. If the rate of dependence was above the median, the chance of the family groups receiving the benefit was twice as low as that of families whose dependence rate was below the median, and the chances were five times higher in families whose IGC value was below the mean compared with those above the mean (Table 4).

The families with the highest chance of receiving the single family subsidy (a proxy variable for the overall family benefits) were those with the following characteristics: relatives, absent father, small size, high rate of dependence and high income generating capacity.

\section{DISCUSSION}

Some $56.0 \%$ of variations in an individual's health conditions are explained by social and ecological factors. There is a substratum of family structure and environment characteristics that enable us to assume that the child's upbringing and family life is less secure and protected. ${ }^{6}$ Mental health complications, history of intra-family violence and drug abuse, followed by unsafe childcare and lack of a father, play an important role in the social and emotional wellbeing of children in their early years, as they can lead to psycho-social difficulties in motor, cognitive and social development and increase the possibility of vulnerability in common activities of their life cycle. ${ }^{11,17,20}$

Aiming to attenuate the harmful impact of social vulnerability on health, the literature specializing in the subject centers on discussing the efficacy and efficiency of systems of social protection, especially as benefits are distributed through different ministries with varying lines of responsibility and accountability. ${ }^{\mathrm{f}}$ In this study, the effectiveness of the social protection system was shown to be unsatisfactory. The transference of social support services, aimed at strengthening the families' parenting skills in situations of stress, depression and family conflict, among others, was poor. ${ }^{25}$ Similar findings have been reported in studies conducted in Colombia and Sweden: recognizing the ineffectiveness and/or failure of the programs. ${ }^{13}$ They also mention how the poor effectiveness of social wellbeing system services on the vulnerable population means there is no decrease in dependence on social assistance services, increasing health inequalities, marginalization and social exclusion. ${ }^{15}$

${ }^{\mathrm{i} L a r r a n ̃ a g a ~ O . ~ L a s ~ n u e v a s ~ p o l i ́ t i c a s ~ d e ~ p r o t e c c i o ́ n ~ s o c i a l ~ e n ~ p e r s p e c t i v a ~ h i s t o ́ r i c a . ~ P r o g r a m a ~ d e ~ l a s ~ N a c i o n e s ~ U n i d a s ~ p a r a ~ e l ~ D e s a r r o l l o ~(P N U D) ~}$ - Chile. Documento de trabajo. 2010-4. Available from: http://www.pnud.cl/areas/ReduccionPobreza/2012/2010_4.pdf 
Table 4. Binary logistic regression analysis between families' structural characteristics and access to the single family subsidy. Metropolitan Region, Chile, 2012.

\begin{tabular}{lc}
\hline Families' structural characteristics & $\beta$ \\
\hline Constant & -0.157 \\
Relatives sharing home & $1.179^{\mathrm{a}}$ \\
Father present & $-1.999^{\mathrm{c}}$ \\
Family size & $-1.424^{\mathrm{b}}$ \\
Dependency rate & 0.710 \\
Household per capita income generating capacity & $1.647^{\mathrm{b}}$ \\
\hline $\mathrm{N}$ & 82 \\
Deviance & 86.896 \\
R2 Nagelkerke & 0.371 \\
Pseudo R2 McFadden & 0.2353 \\
$\%$ correctly predicted cases $(0.5)$ & $76.8 \%$ \\
\hline
\end{tabular}

a Sig. $<0.1$

b Sig. $<0.05$

c Sig. $<0.01$

The ineffectiveness of social support system transfer limits their ability to reduce vulnerability in children, families and communities. ${ }^{25}$ There is a negative cycle of direct and indirect effects on emotional development in children and on health problems in adulthood, evidence of this problem. ${ }^{8}, 16$ Direct effects include genetic factors before birth and affected development after birth. The indirect effects include socioeconomic precariousness, exposure to substance abuse, family conflict and domestic violence. ${ }^{8,20}$

Variables such as family size, absence of father and income generating capacity defined the chance of receiving, or not, the social support benefits studied here. On the other hand, difficulties in the execution of the integrated social protection systems leads to fragmented management, limited resources, lack of confidence and obstacles to adopting an integrated focus and to collaborating. ${ }^{18}$ The association between research and integrated evaluation is essential in analyzing the effectiveness of current practice and of managing the health network and or primary health care. ${ }^{3,19}$ The different factors that affect health need to be critically examined; the strengths and weaknesses of the operative processes between sectors and local institutions, the technical capacities of the institutions involved, the effective availability of resources and information, the relevance of monitoring and evaluation systems, user perception and constructing community alliances. ${ }^{3}$

The evidence reported on the effectiveness of benefit transfer from the Childhood Welfare System to vulnerable families show that its effectiveness was poor in cases that met requirements to receive integrated benefits, especially in families that were extremely socially vulnerable $(12.5 \% ; 16.5 \%$ and $22.6 \%$ respectively, extremely vulnerable; moderately vulnerable and slightly vulnerable).

The background shown here indicates the need to continue with explanatory studies, permitting more in-depth investigation of the data obtained, comparing results in larger and more representative and proportional samples in the respective strata. This would aid in explaining and evaluating the impact and cost effectiveness of the system in equivalent vulnerable populations. In addition to being a requirement for future research, this is a coming challenge for the country; a public policy with copious financial and human resources, aimed at preventing disparities and inequalities in children's health, family health and community health. The issue is responding to the challenges of seeking equality for society's most vulnerable groups through transferring benefits using a compensatory policy in health care.

The limitations of this study are implicit in the above paragraph, referring to the need for more in-depth investigation of the results in future explanatory studies, with more complex sample designs. 


\section{REFERENCES}

1. Arcos $E$, Muñoz LA, Sánchez X, Vollrath A, Latorre C, Bonatti $C$, et al. Vulnerabilidad social en mujeres embarazadas de una comuna urbana de la Región Metropolitana. Rev Med Chile. 2011;139:739-47. Disponible en: http://www.scielo.cl/scielo. php?pid=S0034-98872011000600007\&script=sci_arttext

2. Arcos E, Muñoz LA, Sánchez X, Vollrath A, Gazmuri P, Baeza M. Efectividad del Sistema de Protección Integral de la Infancia en madres y niños vulnerables. Rev Lat Am Enfermagem. 2013;21(5):1071-9. DOI:10.1590/S0104-1169201300050000

3. Baum FE, Legge DG, Freeman T, Lawless A, Labonté R, Jolley $\mathrm{G}$. The potential for multi-disciplinary primary health care services to take action on the social determinants of health: actions and constraints. BMC Public Health. 2013;13:460. DOI:10.1186/1471-2458-13-460

4. Barros FC, Victora CG, Scherpbier R, Gwatkin D. Socioeconomic inequities in the health and nutrition of children in low/middle income countries. Rev Saude Publica. 2010;44(1):1-16. DOI:10.1590/S0034-89102010000100001

5. Behrman JR. How much might human capital policies affect earnings inequalities and poverty? Estud Econ. 2011;38(1):9-41. DOI:10.4067/S0718-52862011000100002

6. Braveman P. Social conditions, health equity, and human rights. Health Hum Rights. 2010;12(2):31-48.

7. Carroll K. Addressing inequality: framing social protection in national development strategies. IDS Bull. 2011;42(6):89-96. DOI:10.1111/j.1759-5436.2011.00279.x

8. Davidson G, Duffy J, Barry L, Curry P, Darragh E, Lees J. Championing the interface between mental health and child protection: evaluation of a service initiative to improve joint working in Northern Ireland. Child Abuse Rev. 2012;21(3):157-72. DOI:10.1002/car.1164

9. Davies JK, Sherriff N. The gradient in health inequalities among families and children: a review of evaluation frameworks. Health Policy. 2011;101(1):1-10. DOI:10.1016/j.healthpol.2010.09.015

10. Devereux S, McGregor JA, Sabates-Wheeler R. Introduction: social protection for social justice. IDS Bull. 2011;42(6):1-9. DOI:10.1111/j.1759-5436.2011.00265.x

11. Hancock KJ Mitrou F, Shipley M, Lawrence D, Zubrick SR. A three generation study of the mental health relationships between grandparents, parents and children. BMC Psychiatry. 2013;13:299. DOI:10.1186/1471-244X-13-299

12. Hunter BD, Neiger B, West J. The importance of addressing social determinants of health at the local level: the case for social capital. Health Soc Care Community. 2011;19(5):522-30. DOI:10.1111/j.1365-2524.2011.00999.x

13. Lampis A. Desafíos conceptuales para la política de protección social frente a la pobreza en Colombia. Rev Estud Soc. 2011;(41):107-21. DOI:10.7440/res41.2011.08
14. Marmot M, Friel S, Bell R, Houweling TA, Taylor $S$. Closing the gap in a generation: health equity through action on the social determinants of health. Lancet. 2008;372(9650):1661-9. DOI:10.1016/S0140-6736(08)61690-6

15. Marttila A, Johansson E, Whitehead M, Burström B. Keep going in adversity: using a resilience perspective to understand the narratives of long-term social assistance recipients in Sweden. Int J Equity Health. 2013;12:8. DOI:10.1186/1475-9276-12-8

16. Mistry KB, Minkovitz CS, Riley AW, Johnson SB, Grason HA, Dubay LC, et al. A new framework for childhood health promotion: the role of policies and programs in building capacity and foundations of early childhood health. Am J Public Health. 2012;102(9):1688-96. DOI:10.2105/AJPH.2012.300687

17. Rossiter C, Fowler C, Mcmahon C, Kowalenko N. Supporting depressed mothers at home: their views on an innovative relationship-based intervention. Contemp Nurse. 2012;41(1):90-100. DOI:10.5172/conu.2012.41.1.90

18. Salari R, Fabian H, Prinz R, Lucas S, Feldman I, Fairchild A, et al. The Children and Parents in Focus project: a population-based cluster-randomised controlled trial to prevent behavioural and emotional problems in children. BMC Public Health 2013;13:961. DOI:10.1186/1471-2458-13-961

19. Sarti S, Alberio M, Terraneo M. Health inequalities and the welfare state in European families. J Sociol SoC Welfare. 2013;40(1):103-30.

20. Small R, Taft AJ, Brown JS. The power of social connection and support in improving health: lessons from social support interventions with childbearing women. BMC Public Health. 2011;11(Suppl 5):S4. DOI:10.1186/1471-2458-11-S5-S4

21. Sojo A. Condiciones para el acceso universal a la salud en América Latina: derechos sociales, protección social y restricciones financieras y políticas. Cienc Saude Coletiva. 2011;16(6):2673-85. DOI:10.1590/S1413-81232011000600002

22. Valenzuela JP, Duryea S. Examinando la prominente posición de Chile a nivel mundial en cuanto a desigualdad de ingresos: comparaciones regionales. Estud Econ. 2011;38(1):259-93. DOI:10.4067/S0718-52862011000100011

23. Venkatapuram S, Bell R, Marmot M. The right to sutures: social epidemiology, human rights, and social justice. Health Hum Rights. 2010;12(2):3-16.

24. Wehby GL, McCarthy AM. Economic gradients in early child neurodevelopment: a multicountry study. Soc Sci Med. 2013;78:86-95. DOI:10.1016/j.socscimed.2012.11.038

25. Yablonski J, Bell B. Responding to vulnerability: the role of social welfare services and cash transfers. Vulnerable Child Youth Stud. 2009;4(Suppl 1):477-80. DOI:10.1080/17450120903128580 